\title{
Needle Biopsy of Liver
}

National Cancer Institute

\section{Source}

National Cancer Institute. Needle Biopsy of Liver. NCI Thesaurus. Code C51675.

Removal of tissue from the liver for microscopic examination, using a needle. 